\title{
Beberapa Isu Haraki di dalam Karya-karya Hadis Sayyid Muhammad Nuh
}

\author{
Several Haraki Issues in the Works of Hadith by Sayyid Muhammad Nuh
}

\author{
MUHAMMAD ARIF YAHYA ${ }^{1}$
}

\begin{abstract}
Sayyid Muhammad Nuh is a prominent 'haraki' figure and has produced a number of works in the field of hadith studies. He has been involved in the dakwa movement of the Muslim Brotherhood which influenced his approach in the production of his works, in terms of the 'haraki manhaj' and methods. Almost all the works of Sayyid Muhammad Nuh emphasized issues of dakwa and tarbiyah, whether in the field of tafsir, hadith, history and issues of the Muslims' society. Moreover, the issues that he highlighted were practical and the application of 'haraki' approach in production of writings brought about significant lesson to the dakwa movement, including the ones in the field of hadith. The author presents three of his works in the field of hadith which have been among the most referred and widely read in the dakwa circle, including the dakwa movement in Malaysia. His selected works in the field of hadith are 'Tawjihat of the Prophet 'ala al-Tariq' (Hadiths of Guidance on the Dakwa Path), 'Manhaj al -Rasul fi Ghars Ruh al-Jihad fi Nufus Ashabih' (The Messenger's Approach in Inspiring Spirit of al-Jihad in the Companions), and 'Min Akhlaq al-Nasr fi Jiyl al-Sahabah' (Winning Attitudes in the Generation of the Companions). Through this article, the authors highlights a number of 'haraki' issues based on the works of Sayyid Muhammad Nuh and the important lessons that he has highlighted for the people of dakwa in facing the dakwa path, based on the hadith of the Messenger.
\end{abstract}

Keywords: haraki, hadith, Islamic movement, Sayyid Muhammad Nuh

Sayyid Muhammad Nuh (m. 2007M) merupakan salah seorang tokoh haraki dalam gerakan dakwah semasa dan telah menghasilkan beberapa karya dalam bidang pengajian hadis. Penglibatan beliau di dalam Gerakan Ikhwan Muslimin mempengaruhi pendekatannya dalam penulisan karya dengan manhaj haraki tidak terkecuali karya-karya beliau dalam bidang hadis. Pada hakikatnya, manhaj haraki memang wujud dalam sirah perjalanan Nabi (s.a.w.) dan para Salaf al-salih terdahulu. Seluruh kehidupan Rasulullah (s.a.w.) bersama para sahabat patut dijadikan contoh teladan khususnya dalam usaha membina sebuah harakah dakwah dan jemaah yang bergerak di medan dakwah secara lebih sistematik (al-Ghadban 1990: 7-13). Malah salah satu ciri yang wujud dalam manhaj agama Islam ini ialah al-waqi ìyyah al-harakiyyah seperti mana yang disebutkan oleh Sayyid Qutb (1979: 57). Akan tetapi, segelintir para pendakwah (sama ada secara individu atau organisasi) tidak memahami aspek haraki dalam melaksanakan kefahaman haraki secara lebih tepat dan berkesan. Dakwah yang digerakkan bukan hanya setakat aspek intelektual (thaqafi), spiritual (ruhi), politik (siyasi) atau penumpuan hanya pada aspek tertentu, tetapi perlu difahami dengan luas secara lebih syumul. Artikel ini mengkaji

\footnotetext{
${ }^{1}$ Muhammad Arif Yahya, M.A., Fellow at Dept. of Theology and Philosophy, Faculty of Islamic Studies, Universiti Kebangsaan Malaysia, 43600 BANGI, Selangor, Malaysia, email: arifyahya87@gmail.com.
} 
secara khusus karya-karya Sayyid Nuh dalam bidang hadis dan melihat beberapa isu haraki yang diketengahkan oleh Sayyid Muhammad Nuh di dalam karya-karya hadis ini.

\section{Konsep Haraki}

Kalimah haraki dinisbahkan kepada kalimah harakah yang berasal dari kata dasar haruka, yahruku, harkan dan harakatan yang bermaksud 'pergerakan' dan antonim kepada sukun iaitu 'kaku' atau 'tidak bergerak' ('Abduh et al. t.t.: 309). Harakah juga diertikan sebagai keadaan tubuh yang berubah kedudukannya secara berterusan. Perkataan harakah atau harakiyyah juga lebih sinonim dengan istilah dakwah (al-Khalidi 2000: 80). Apabila disebutkan harakah yang dimaksudkan dengannya adalah harakah da'wah. Ia merupakan istilah baru berkaitan politik dan gerakan, selain banyak digunakan bagi menghubungkan aktiviti dakwah Islamiyyah yang mengajak kepada pembaharuan (tajdid) dan pelaksanaan Islam (di atas muka bumi) (Makki 1995: 1-2; Haziyah \& Sohirin 2012: 69). Menurut Salah al-Khalidi, istilah haraki merupakan istilah baru yang dikaitkan dengan dakwah semasa dan dicetuskan pada peringkat permulaannya oleh Sayyid Qutb melalui beberapa penulisannya, terutamanya kitab Fi Zilal alQuran (al-Khalidi 2012). Walaupun begitu, konsep haraki itu sendiri secara mafhumnya telah wujud sejak dari zaman Rasulullah (s.a.w.) dan para sahabat r.a. lagi (Qutb 1979: 57). Malah keperibadian Salaf al-salih seperti Ahmad bin Hanbal (m. 241H) dan Ahmad bin Abd al-Halim, Ibn Taymiyyah (m. 728H) dalam menghadapi situasi dakwah pada ketika itu boleh dianggap sebagai keperibadian da ì haraki dalam menyebarkan dakwah ketika itu (al-Khalidi 2012).

\section{Aliran al-Haraki dalam Hadis}

Sayyid Qutb dianggap sebagai pelopor kepada kemunculan aliran al-Haraki di dalam bidang tafsir. Menurut Salah al-Khalidi (2012), aliran penafsiran seperti ini bermula dengan gerak kerja dan amal dakwah yang muncul dalam harakah Islamiyyah Ikhwan Muslimin. Aliran al-Haraki ini diberi juga dengan jolokan Madrasah al-Haraki fi al-Tafsir yang diasaskan oleh Sayyid Qutb ini dan telah diikuti oleh tokoh-tokoh tafsir lain yang turut terlibat di dalam gerak kerja dakwah Ikhwan Muslimin seperti Baha' al-Khuwliy, Muhammad al-Ghazali, Sa id Hawwa, 'Abd alMuta`al al-Jabari, Adnan Zarzur, Ahmad Farhat, Muhammad al-Sabbagh (al-Khalidi 2010: 46). Bermula dengan pengajian al-Quran ini, kecenderungan tokoh-tokoh dakwah ke arah penggunaan manhaj haraki ini terus berkembang dalam bidang pengajian hadis pula. Pendekatan dalam memahami hadis-hadis Nabi (s.a.w.) juga disesuaikan dengan matlamat harakah dakwah seperti mana pendekatan dalam pentafsiran al-Quran. Perkara ini adalah bertitik tolak dari keterlibatan para ulama haraki ini dalam gerakan dakwah semasa sehingga mempengaruhi kecenderungan dan pendekatan mereka dalam pentafsiran al-Quran dan penghuraian hadis-hadis Nabi (s.a.w.) dari aspek haraki. Antara tokoh yang mengambil pendekatan haraki dalam penghuraian hadis-hadis Nabi (s.a.w.) ialah Muhammad Qutb melalui kitabnya Qabasat min al-Rasul (s.a.w.), Hisham Saqr melalui kitabnya Ghulam al-Da wah: Durus fi Hadis al-Sahir wa al-Ghulam wa al-Rahib dan Sayyid Muhammad Nuh melalui beberapa kitab beliau Taujihat Nabawiyyah 'ala al-Tariq, Manhaj al-Rasul fi Ghars Ruh al-Jihad fi Nufus Ashabih dan Min Akhlaq al-Nasr fi Jiyl al-Sahabah.

\section{Sayyid Muhammad Nuh: Tokoh Dakwah dan Haraki}

Sayyid Muhammad Nuh dilahirkan di 'Uzbah al-Siba`i, daerah Kafr al-Shaykh, Mesir pada 23 Jumada al-Ula 1365, bersamaan 24 April tahun 1946M (al-Husayn 2010). Dibesarkan di kampung dalam keluarga yang cukup sederhana dan miskin. Beliau berjaya menamatkan hafalan al-Quran sewaktu usianya 8 tahun. Setelah itu, beliau menyambung pengajian di Ma`ahad al-Azhari al-Ibtida'i di Kafr al-Shaykh. Kemudian memasuki peringkat menengah di 
Ma`ahad al-Mahallah al-Azhari al-Thanawi. Ketika di alam persekolahan menengah lagi, Sayyid Nuh banyak mengikuti program tasawuf dari beberapa orang gurunya, antaranya `Abd al-Salam Abu al-Fadl, yang merupakan guru beliau dalam mengesani jiwa dan kerohaniannya. Teman rapat dan rakan seperjuangan Sayyid Nuh ketika berguru dengan `Abd al-Salam Abu al-Fadl ialah Yahya Ismail yang kemudiannya berperanan dalam memperkenalkan kepada Sayyid Nuh, dakwah haraki Ikhwan Muslimin (Ubadah Sayyid Nuh 2012). Di dalam bidang akademik, minat Sayyid Nuh begitu mendalam dalam bidang pengajian hadis dan mendorongnya untuk melanjutkan pelajaran sehingga ke peringkat Ph.D dalam bidang ini. Beliau menamatkan ijazah pertama di Universiti al-Azhar pada tahun 1971M (al-Husayn 2010). Kemudian melanjutkan pelajaran ke peringkat Sarjana dan berjaya menamatkan pengajiannya pada tahun 1973 dengan disertasi kajian bertajuk Perkahwinan Rasulullah (s.a.w.) dengan Zaynab binti Jahsy; Menolak Tohmahan Sekitar Perkahwinan itu berdasarkan Manhaj Golongan Muhaddisin. Kemudian beliau melanjutkan pelajaran ke peringkat Ph.D dan berjaya menamatkan pengajiannya pada tahun 1976 dengan tajuk tesis kajian Al-Hafiz Abu al-Hajjaj Yusuf al-Mizzi dan Kesungguhannya dalam Penulisan Tahdhib al-Kamal dan meraih tempat cemerlang (mumtaz) bagi kajian tesis ini. Sayyid Nuh telah menunjukkan ketokohannya dalam menyerlahkan sumbangan al-Hafiz al-Mizzi melalui penghasilan tesis Ph.D. Hasil penemuan kajian bagi tesis ini juga telah memberikan suatu gambaran yang jelas kepada penuntut ilmu hadis pada ketika itu, khususnya di Universiti al-Azhar sendiri dalam memahami dengan lebih baik kandungan kitab Tahdhib al-Kamal (Yahya Ismail 2012).

Penglibatan beliau dalam gerakan dakwah Ikhwan Muslimin pada mulanya ketika beliau mula berjinak mengikuti penulisan 'Umar al-Tilmisani di dalam Majallah al-Da'wah alIkhwaniyyah. 'Umar Tilmisani adalah merupakan Mursyidul Am ketiga Ikhwan Muslimin setelah kematian Mursyidul Am yang kedua, iaitu Hasan al-Hudaybi pada tahun 1973. Di samping membaca dari tulisan-tulisan haraki Majallah al-Da'wah al-Ikhwaniyyah ini, beliau juga mengikuti program-program yang dikendalikan oleh Shaykh Muhammad al-`Adawi di perkampungan Mahallah Abu `Ali, Mahallah al-Kubra, Mesir (Ikhwan wiki 2013). Sayyid Nuh mengikuti program ini bersama-sama dengan teman rapatnya Yahya Isma'il yang ketika itu banyak menyalurkan fikrah-fikrah Ikhwan ke dalam kehidupan Sayyid Nuh (Yahya Ismail 2012). Sejak mengikuti program tersebut dan terkesan dengan sentuhan Shaykh Muhammad al'Adawi, beliau mula melibatkan diri secara aktif dalam gerakan dakwah Ikhwan Muslimin (Wasfi Asyur 2013).

Sayyid Muhammad Nuh keluar dari Mesir tahun 1981 pada asalnya memenuhi jemputan sebagai Pensyarah Pelawat di Universiti Qatar. Pada ketika itu juga, keadaan di Mesir tidak stabil dan ramai dari anggota Ikhwan Muslimin telah ditangkap dan dipenjarakan. Sayyid Muhammad Nuh juga merupakan salah seorang anggota Ikhwan yang disenaraikan dalam perintah penangkapan tersebut. Kalaulah tidak kerana panggilan sebagai pensyarah jemputan ke Universiti Qatar tersebut, Sayyid Muhammad Nuh kemungkinan akan ditangkap dan dipenjaran bersama anggota Ikhwan yang lain. Beliau telah berkhidmat di Universiti Qatar selama setahun (1981-1982). Kemudian beliau merantau di beberapa Universiti di Emiriah dan Dubai bermula tahun 1982 dan berakhir di Universiti Kuwait setelah menetap di sana bermula tahun 1993 sehingga beliau meninggal dunia tahun 2007 (Yahya Ismail 2012; al-Husayn 2010).

\section{Karya-Karya Hadis Sayyid Nuh: Pengenalan dan Metode Penulisan}

Di bawah perbahasan berikut ini, penulis mengemukakan beberapa karya hadis Sayyid Muhammad Nuh dengan mengkaji metode penulisan serta pendekatan beliau dalam penghuraian hadis-hadis ini dari aspek haraki. 


\section{Taujihat al-Nabawiyyah 'ala al-Tariq}

Kitab Taujihat Nabawiyyah 'ala al-Tariq merupakan sebuah kitab yang menghimpunkan hadishadis bimbingan dan petunjuk untuk para pendakwah dalam meniti liku-liku jalan dakwah. Sayyid Muhammad Nuh memilih 40 teks hadis untuk dihuraikan satu persatu dan dibincangkan setiap kandungannya dalam konteks dakwah dan harakah. Cetakan pertama bagi kitab ini ialah cetakan Dar al-Wafa, Mansurah, Mesir yang diterbit pada tahun 1992. Penulis merujuk cetakan Dar al-Yaqin, Mansurah, Mesir, yang diterbit pada tahun 1998. Kitab ini mengandungi 3 juzuk dan dicetak dalam 2 jilid bagi versi cetakan Dar al-Yaqin. Kitab ini turut diterjemahkan ke bahasa Indonesia (jilid pertama) dan dijual di pasaran Malaysia dengan tajuk buku Pesan-Pesan Nabi (s.a.w.): Syarah Hadits dalam Perspektif Dakwah dan Tarbiyah, terbitan an-Nadwah, Jakarta, tahun terbitan 2004 dan diterjemah oleh Fadhli Bahri (2004). Antara metode penulisan Sayyid Nuh dalam menyusun kitab ini seperti berikut:

a. Memulakan hadis yang pertama berkaitan dengan Seorang Mukmin Yang Kuat Lebih Dikasihi oleh Allah Berbanding Seorang Mukmin Yang Lemah.

b. Menghuraikan hadis-hadis Nabi (s.a.w.) dengan dalil-dalil yang ma 'thur.

c. Tidak meletakkan tajuk pada setiap permulaan hadis. Hanya sekadar menyebutkan nombor hadis, sebagai contoh hadis pertama : "الحديث الأول".

d. Menfokuskan kepada penyatuan saf umat Islam. Mengelak dari banyak berbincang tentang permasalahan fiqh dan perbezaan pandangan ulama.

e. Mengemukakan sebahagian huraian dalam bentuk dialog dan analogi yang membantu proses pemahaman sesuatu isu.

f. Mengemukakan jalan penyelesaian dan alternatif dalam sesuatu permasalahan dakwah.

g. Membawa huraian bahawa setiap muslim adalah $d a^{\prime} i$, bertanggungjawab mengajak individu yang lain kearah ketaatan pada Allah (s.w.t.) mengikut kemampuan masing-masing.

h. Meletakkan di setiap akhir perbincangan hadis, satu tajuk berkaitan istifadah dan "ما يستفاد من pengajaran dari hadis dari sudut dakwah dan tarbiyah, dengan tajuk

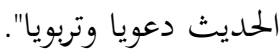

\section{Manhaj al-Rasul fi Ghars Ruh al-Jihad fi Nufus Ashabih}

Karya ini ditulis oleh Sayyid Nuh bagi mengkaji metode Rasulullah (s.a.w.) dalam meniupkan semangat jihad dalam diri para sahabat. Beliau menyusun karya ini dengan membahagikannya kepada dua bahagian. Bahagian pertama, melihat kepada isi kandungan dan inti sari dari metode Rasulullah (s.a.w.) Manakala bahagian kedua, berkaitan uslub dan wasilah yang digunakan oleh Rasulullah (s.a.w.) dalam meniupkan semangat jihad ini. Karya asal bagi kitab ini adalah cetakan Dar al-Wafa, Mansurah, Mesir, dan cetakan pertamanya telah diterbitkan pada tahun 1991. Karya ini juga turut diterjemah ke dalam bahasa Indonesia dengan tajuk Metode Rasulullah (s.a.w.) dalam Meniupkan Semangat Roh al-Jihad dalam Diri Para Sahabat. Antara metode penulisan kitab ini seperti mana berikut :

a. Membahagikan kitab kepada dua bahagian, bahagian pertama, melihat kepada isi kandungan dan inti sari dari metode Rasulullah (s.a.w.) Manakala bahagian kedua, berkaitan uslub dan wasilah yang digunakan oleh Rasulullah (s.a.w.) dalam meniupkan semangat jihad. 
b. Meletakkan sub topik berkaitan metode Rasulullah (s.a.w.) dalam kedua-dua bahagian, iaitu lima topik dalam bahagian pertama dan lima topik dalam bahagian kedua.

c. Mukaddimah kitab dimulakan dengan tajuk Hakikat Jihad yang Ditiupkan oleh Rasulullah (s.a.w.) ke dalam Diri Para Sahabat, sebelum mengemukakan perbincangan ke atas kedua-dua bahagian berkaitan manhaj Rasulullah (s.a.w.)

d. Mengemukakan ayat-ayat al-Quran bagi menyokong kenyataan di samping sirah yang dinyatakan bagi menambah kefahaman.

e. Setiap akhir tajuk perbahasan, Sayyid Nuh sering kali menyeru ke arah kefahaman jihad yang betul dan sepatutnya difahami dengan konsepkefahaman salaf al-soleh dahulu.

\section{Min Akhlaq al-Nasr fi Jiyl al-Sahabah}

Karya Min Akhlaq al-Nasr fi Jiyl al-Sahabah (Akhlak-Akhlak Kemenangan dalam Generasi Para Sahabat) membincangkan aspek kemenangan dalam keperibadian dan akhlak para sahabat yang telah dididik oleh Nabi (s.a.w.) Karya ini telah dicetak dengan cetakan Dar Ibn Hazm, Beirut, Lubnan, tahun cetakan 1994. Karya ini juga telah diterjemah ke dalam bahasa Indonesia dengan karya terjemahan bertajuk Berguru Kepada Sahabat Nabi (s.a.w.), cetakan Era Intermedia, Solo, Indonesia. 2008. Penterjemahnya ialah Solihin. Antara metode penulisan bagi kitab ini:

a. Terdapat 14 akhlak kemenangan para sahabat yang disenaraikan oleh Sayyid Nuh di dalam kitab ini.

b. Sayyid Muhammad Nuh menghuraikan setiap akhlak kemenangan dalam diri para sahabat dengan dalil-dalil ma'thur (al-Quran dan al-Hadis).

c. Kemenangan yang dimaksudkan oleh Sayyid Nuh adalah suatu pendekatan dan kefahaman yang syumul. Bukan hanya kemenangan yang dilihat dari sudut zahir semata-mata, tetapi akhlak kemenangan dari sudut spiritual (ruhi) tetap sama dititik beratkan. Malah dari sudut strategi dan persediaan ke arah mencapai kemenangan tersebut turut ditekankan oleh Sayyid Nuh di dalam karya ini.

d. Di akhir setiap perbincangan berkaitan akhlak kemenangan para sahabat, Sayyid Nuh akan mengemukakan cadangan dan saranan beliau bagi mengatasi permasalahan yang timbul khususnya berkaitan sikap umat Islam kini yang jauh dari meraih kemenangan seperti mana para Salafal-salih.

\section{Beberapa Isu Haraki dalam Karya-karya Hadis Sayyid Muhammad Nuh}

Isu-isu haraki yang dimaksudkan di sini adalah yang menjurus ke arah perbincangan berkaitan dengan gerakan dakwah. Berikut ini adalah merupakan perincian perbahasan beberapa isu haraki dalam karya-karya hadis Sayyid Nuh:

\section{Harakah dari Sudut Amal Fardi}

Amal fardi yang dimaksudkan ini ialah amalan yang perlu dijaga oleh seorang pendakwah sebagai tuntutan asas ke atasnya dan bekalan dalam kehidupan dakwahnya (Sayyid Nuh 1991: 37). Perkara ini banyak ditekankan oleh Sayyid Muhammad Nuh dalam karya-karya hadis beliau dan membincangkan tentang amalan da`i secara individu yang sepatutnya dijaga sebagai bekalan dalam mengharungi cabaran di atas jalan dakwah. Di dalam kitab Taujihat Nabawiyyah 'ala al-Tariq, antara hadis yang dikemukakan oleh Sayyid Nuh berkaitan isu harakah dari sudut amal fardi ini iaitu hadis yang keenam seperti mana berikut: 


$$
\text { وعن صلى الفجر في جماعة، ثم قعد يذكر الله حتى تطلع الشمس، ثم صلى ركعتين، كانت له كأجر حجة، }
$$

\begin{abstract}
Maksudnya: Sesiapa yang mengerjakan solat Fajar (Subuh) secara berjemaah, kemudian duduk sebentar melakukan zikir pada Allah sehingga terbitnya matahari, kemudian mengerjakan solat sunat dua rakaat, baginya pahala seperti mengerjakan haji dan umrah secara sempurna, sempurna. [Hadis diriwayatkan oleh Imam Tirmidhi dan dihasankan oleh al-Albani].
\end{abstract}

Melalui hadis ini, Sayyid Nuh menyatakan pengajaran hadis dari sudut tarbiyah dan dakwah iaitu kepentingan menghidupkan waktu selepas solat subuh dengan zikir dan tilawah sehingga terbitnya matahari dan diakhiri dengan solat sunat dua rakaat. Amalan seperti ini merupakan antara amalan yang perlu dijaga oleh seorang da i sebagai salah satu elemen haraki dalam amal fardi seseorang da i. Seseorang da ì perlu menjaga dan menghidupkan waktu-waktu seperti ini, sebagai bekalan kerohaniannya sekiranya pada waktu itu tidak ada tugasan lain yang perlu ditunaikan (Sayyid Nuh 1998: 41). Menurut Sayyid Muhammad Nuh lagi, waktu seperti ini juga selain ganjaran yang besar diperuntukkan bagi yang menghidupkannya, ia juga baik untuk kesihatan diri, dengan udara yang segar dan tidak dicemari dengan perkara kemaksiatan dan kejahatan manusia (Sayyid Nuh 1998: 41).

\title{
Harakah dari Sudut Amal Jama $i$
}

Harakah dari sudut amal jama $i$ di sini dengan maksud harakah (pergerakan) yang didasarkan dengan gerak kerja berkumpulan. Di dalam dakwah, salah satu perkara penting dalam mendidik jiwa pendakwah ialah sikap amal jama i serta gerak kerja secara kolektif dan tidak bersifat individualistik. Di dalam Kitab Min Akhlaq al-Nasr Fi Jiyl al-Sahabah, Sayyid Nuh menyebutkan hadis tentang kewajipan dalam amal jama $i$ ketika menghuraikan salah satu akhlak kemenangan di dalam keperibadian para sahabat iaitu akhlak 'bersatu dan berganding tangan'. Hadis yang dimaksudkan itu seperti berikut:

$$
\text { من فارق الجماعة شبرا، فقد خلع ربقة الإسلام من عنقه. رواه أبو داود وصححه الألباني }
$$

Maksudnya: Sesiapa yang berpisah daripada jemaah walaupun kadar sejengkal, maka dia telah mencabut tali ikatan Islam daripada tengkuknya. [Hadis ini diriwayatkan oleh Abu Daud dan disahihkan oleh al-Albani].

Begitu juga di dalam karya-karya hadis beliau yang lain iaitu kitab Taujihat Nabawiyyah ala al-Tariq yang turut mengemukakan hadis yang sama pada perbahasan hadis yang ke-21 dari kitab ini (Sayid Nuh 1998: 1: 154). Begitu juga di dalam karya Manhaj al-Rasul fi Ghars Ruh al-Jihad fi Nufus Ashabih yang turut menekankan aspek amal jama i ini ketika menyebutkan salah satu metode Rasulullah (s.a.w.) dalam meningkatkan roh jihad para sahabat iaitu dengan melakukan bai'ah yang salah satu darinya berkaitan dengan 'bai'ah dalam melaksanakan tugasan dakwah' (Sayyid Nuh 1991: 110). Salah satu isu haraki yang sering ditekankan dalam karya hadis Sayyid Nuh ialah berkaitan dengan aspek jihad di dalam gerak kerja (harakah). Di dalam kitab Taujihat Nabawiyyah 'ala al-Tariq, Sayyid Muhammad Nuh ada mengemukakan beberapa hadis dalam membincangkan aspek jihad ini, antaranya hadis yang ke-25 seperti mana berikut : 


$$
\text { كل ميت يختم على عمله إلا المرابط في سبيل الله، فإنه ينمي له عمله إلى يوم القيامة، ويؤمن فتنة القبر. رواه }
$$

\begin{abstract}
Maksudnya: Setiap kematian akan terhenti amalannya kecuali (golongan) al-Murabit (pejuang) di jalan Allah, kerana sesungguhnya amalan mereka akan digandakan sehingga hari kiamat, serta mereka aman dari fitnah kubur. [Hadis ini diriwayatkan oleh Abu Daud dan disahihkan oleh al-Albani].
\end{abstract}

Hadis ini menggambarkan tentang kelebihan yang diraih oleh golongan al-Murabit $f i$ sabil Allah, iaitu mereka yang berjihad dan berjuang di jalan Allah, termasuk para penggerak dakwah dan mereka yang mempertahankan kebaikan dari serangan kebatilan (Sayyid Nuh 1998: 1\&2: 257-260). Sayyid Nuh ketika menghuraikan hadis ini menyebutkan bahawa al-Ribat yang dimaksudkan sebagai kelompok yang mempertahankan kedudukan Islam di medan peperangan adalah maksud al-Ribat secara khusus. Adapun maksud al-Ribat secara umum iaitu sikap sentiasa bersedia dan bersiap siaga untuk berjihad dalam semua keadaan. Ia meliputi alRibat dengan maksud yang khusus dan meliputi sikap untuk sentiasa menjauhi segala kemaksiatan dan kejahatan sama ada yang kecil atau yang besar, secara zahir atau tersembunyi. Begitu juga dengan amalan ketaatan bermula dari kalimah La Ilaha Illa Allah sehingga membuang onak dan duri dari jalanan serta dakwah yang digerakkan untuk kebaikan dengan menyuruh kepada yang makruf dan mencegah dari kemungkaran. Kesemua ini termasuk dalam maksud hadis sebagai golongan al-Murabitin yang layak mendapat ganjaran besar yang disebutkan di dalam hadis iaitu mengalir segala pahala dan kebaikannya serta berkembang walaupun ketika berada di alam Barzakh (Sayyid Nuh 1998: 1\&2: 258). Sayyid Muhammad Nuh juga mengemukakan hadis yang lain dari kitab Taujihat Nabawiyyahini yang turut menekankan aspek jihad dalam harakah dakwah, seperti hadis yang ke-30 dari kitab ini.

\title{
Harakah Secara Berperingkat-peringkat (Tadarruj)
}

Di dalam kitab Manhaj al-Rasul fi Ghars Ruh al-Jihad fi Nufus Ashabih, Sayyid Nuh mengemukakan pengajaran harakah secara berperingkat-peringkat ini dengan mengambil contoh konsep jihad yang ditanam dalam diri para sahabat. Peringkat pertama ialah peringkat mengislah diri dan mendidik nafsu. Peringkat ini juga adalah peringkat mendidik kesabaran dan ketahanan fizikal para sahabat. Antara hadis yang dikemukakan oleh Sayyid Muhammad Nuh:

$$
\begin{aligned}
& \text { عن أبي عبدالله خباب بن الأرت رضي الله عنه قال: شكونا إلى رسول الله صلى الله عليه وسلم : وهو }
\end{aligned}
$$

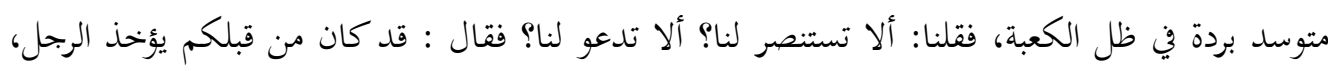

$$
\begin{aligned}
& \text { فيحفر له في الأرض فيجعل فيها، فيجاء بالمنشار، فيوضع على رأسه، فيجعل نصفين، ويمشط بأمشاط }
\end{aligned}
$$

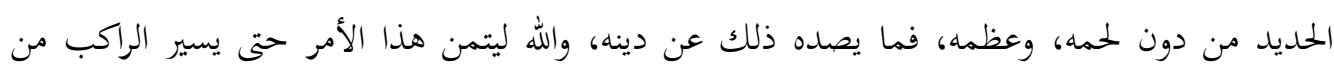

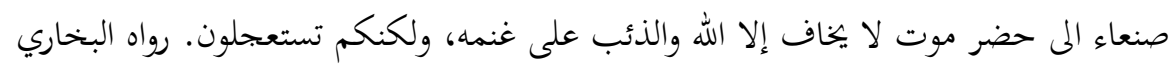

Terjemahan: Daripada Abu Abd Allah Khabbab bin al-Arat r.a. katanya: Kami mengadu kepada Rasulullah (s.a.w.) dan beliau ketika itu berbaring di bawah naungan Kaabah berbantalkan serban. Maka kami bertanya: Apakah tuan tidak berdoa memohon kemenangan bagi pihak kita? Adakah tidak tuan berdoa bagi pihak kita? Maka Rasulullah (s.a.w.) berkata: Sesungguhnya orang-orang sebelum kamu, ditangkap seorang lelaki lantas digali lubang lalu ia ditanam di dalamnya, kemudian dibawa datang gergaji lalu digergaji kepalanya sehingga terbelah dua dan disikat badaknya dengan sikat besi sehingga meluruhkan daging dan tulangnya, namun demikian itu tidak memalingkan ia 
dari agamanya. Demi Allah, nescaya Allah menyempurnakan urusan ini (agama Islam) sehinggalah musafir dari Sana'a ke Hadhramawt tidak lagi takut melainkan hanya kepada Allah, akan tetapi kamu adalah golongan yang gopoh. [Hadis ini diriwayatkan oleh Imam Bukhari di dalam Sahihnya].

Setelah peringkat mendidik kesabaran dan ketahanan fizikal kepada para sahabat, muncul pula peringkat arahan supaya berhijrah sama ada berhijrah ke Habsyah atau ke Madinah al-Munawwarah. Setelah itu, barulah muncul peringkat berperang dengan tentera yang memerangi Islam (Sayyid Nuh 1991: 100). Berdasarkan kefahaman dari hadis di dalam karya Sayyid Nuh ini telah membentuk suatu kaedah umum dalam menggerakkan dakwah harakah iaitu keperluan kepada harakah secara berperingkat-peringkat serta menilai sesuatu jalan penyelesaian dakwah secara terancang, selain jauh dari unsur isti jal atau gopoh gapah.

\section{Harakah ke arah Kemenangan dan Penguasaan di atas Muka Bumi (Khilafah)}

Dakwah yang ingin diketengahkan bukan hanya bersifat mahalli (lokaliti) bahkan ia bersifat 'alami (sedunia), seperti mana maratib al-'amal (peringkat gerak kerja dalam dakwah) yang telah ditetapkan oleh Hasan al-Banna di dalam Himpunan Risalahnya (al-Banna 1992: 359361). Sayyid Nuh membawa pengajaran haraki dari hadis-hadis yang dikemukakannya berdasarkan kaedah dan pemahaman ini. Malah salah satu marhalah penting dan pengajaran dari manhaj haraki dalam Sirah Baginda (s.a.w.) seperti mana yang disebutkan oleh Munir alGhadban di dalam kitabnya bertajuk Al-Manhaj al-Haraki li al-Sirah al-Nabawiyyah ialah menggerakkan dakwah dan menyebarkannya ke luar Semenanjung Tanah Arab (al-Ghadban 1990: 9 \& 16). Sayyid Muhammad Nuh menyebutkan di dalam karya beliau Min Akhlak al-Nasr fi Jiyl al-Sahabahbahawa salah satu akhlak kemenangan para sahabat ialah akhlak 'Yakin dengan Pertolongan Allah (s.w.t.)' Di dalam perbincangan di bawah tajuk ini, Sayyid Nuh mengemukakan beberapa ayat al-Quran dan hadis-hadis Nabi (s.a.w.) dalam menggambarkan akhlak keyakinan yang dididik dalam meraih kemenangan di dalam diri para sahabat. Antara hadis yang dikemukakan Sayyid Nuh seperti mana berikut :

$$
\begin{aligned}
& \text { تكون النبوة فيكم ماشاء الله أن تكون، ثم يرفعها إذا شاء أن يرفعها، ثم تكون خلافة على منهاج النبوة، } \\
& \text { فتكون ماشاء الله أن تكون، ثم يرفعها إذا شاء أن يرفعها، ثم تكون ملكا عاضا، فيكون ماشاء الله أن يكون، } \\
& \text { ثم يرفعها إذا شاء أن يرفعها، ثم تكون ملكا جبرية فتكون ماشاء الله أن تكون، ثماء يرفعها إذا شاء أنهاء أن يرفعها، }
\end{aligned}
$$

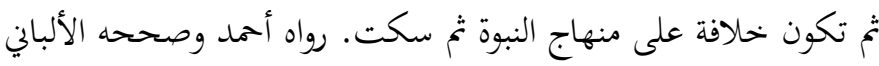

Maksudnya: Akan berlaku zaman pemerintahan Nubuwwah seperti yang dikehendaki Allah untuk berlaku, kemudian diangkat zaman tersebut seperti yang dikehendaki untuk mengangkatnya, kemudian berlaku zaman pemerintahan khilafah dengan manhaj alnubuwwah, maka berlaku seperti yang dikehendaki Allah untuk berlaku, kemudian diangkat zaman tersebut sekiranya dikehendaki untuk mengangkatnya, kemudian berlaku zaman pemerintahan raja yang zalim, berlaku seperti yang dikehendaki Allah untuk berlaku, kemudian diangkat zaman tersebut sekiranya dikehendaki untuk mengangkatnya, kemudian berlaku zaman pemerintahan raja yang jahat, maka berlaku seperti yang dikehendaki Allah untuk berlaku, kemudian diangkat zaman tersebut sekiranya dikehendaki untuk mengangkatnya, kemudian berlaku zaman pemerintahan khilafah dengan manhaj al-nubuwwah. .. [Hadis ini diriwayatkan oleh Ahmad dan disahihkan oleh al-Albani].

Sayyid Muhammad Nuh menegaskan bahawa para sahabat telah dididik dengan keyakinan bahawa golongan beriman akan meraih kemenangan dan keteguhan di atas muka 
bumi dalam perjuangan menegakkan Islam (Sayyid Nuh 1994: 129). Keyakinan tersebut membawa suatu harapan yang positif di dalam diri para sahabat, tambahan pula keyakinan yang disandarkan kepada Allah (s.w.t.) dalam mencapai kemenangan umat Islam. Sayyid Muhammad Nuh juga meyakinkan bahawa umat Islam kini juga mampu meraih kemenangan yang sama dan layak mendapat bantuan dari Allah (s.w.t.) seperti mana yang diraih oleh generasi para sahabat dahulu, tetapi dengan syarat umat Islam kini perlu mencontohi akhlak kemenangan para sahabat dengan meyakini tanpa syak bahawa janji Allah (s.w.t.) tentang kemenangan dan keteguhan akan muncul dan tiada mustahil lagi walaupun dalam tempoh yang difikirkan agak panjang (Sayyid Nuh 1994: 129).

Sebagai kesimpulan, isu-isu haraki yang ditekankan oleh Sayyid Muhammad Nuh di dalam karya-karya hadis beliau adalah merupakan isu-isu besar dalam konsep memahami gerak kerja harakah dakwah semasa. Isu-isu ini digarap melalui kefahaman terhadap konsep dan maksud dari definisi haraki itu sendiri sepertimana definisi yang dikemukakan oleh Salah al-Khalidi dan tokoh-tokoh haraki yang lain. Malah usaha Sayyid Muhammad Nuh dalam mengemukakan huraian dan pengajaran hadis-hadis dari aspek haraki ini bertitik tolak dari latar belakang beliau yang banyak terkesan dengan didikan dari tokoh-tokoh haraki dan gerakan dakwah semasa. Berdasarkan hadis-hadis yang telah diulas dengan pendekatan haraki seperti mana dalam huraian isu-isu yang telah dikemukakan melalui artikel ini menunjukkan bahawa harakah dan gerak kerja dalam gerakan dakwah semasa boleh difahami dan disuluh panduan melalui pengajaran dari hadis-hadis Nabi dan sunah Baginda (s.a.w.) Malah dengan pengalaman yang luas yang dimiliki oleh Sayyid Muhammad Nuh dalam gerak kerja harakah dakwah di samping keautoritian dan kepakaran beliau dalam bidang pengajian hadis memberikan nilai tambah dan kekuatan tersendiri terhadap karya-karya hadis yang telah dihasilkannya dan pengajaran yang dikemukakan beliau dalam bidang dakwah dan gerakan Islam semasa.

\section{References}

'Abduh, Daud et al. t.th. Al-Mu jam al-asasi al-Arabi. t.tp.: t.pt.

al-Albani, Muhammad Nasir al-Din. 1989. Sahih Sunan al-Tirmidhi bi al-ikhtisar al-sanad. AlRiyad: Maktabah al-Tarbiyah al-'Arabi li Duwal al-Khalij.

al-Asy'ath, Abu Daud Sulaiman. 1999. Sunan Abi Daud. Tahqiq Sayyid Muhammad Sayyid, Abd al-Qadir al-Khayr \& Sayyid Ibrahim. Cairo: Dar al-Hadith.

Badlihisham Mohd Nasir. 2009. Dinamisme gerakan Islam dan cabaran semasa. Shah Alam: Karisma Publication.

al-Banna, Hasan. 1992. Majmu'ah rasail al-Imam al-Syahid Hasan al-Banna. Cairo: Dar al-Tawzi` wa al-Nasyr al-Islamiyyah.

al-Bukhari, Muhammad b. Ismail. 2002. Sahih al-Bukhari. Cet. Ke-2. Beirut: Dar al-Kutub al'Ilmiyyah.

al-Ghadban, Munir. 1990. Al-manhaj al-haraki li al-Sirah al-Nabawiyyah. Cet. Ke-6. Al-Zarqa': Maktabah al-Manar.

Haziyah Hussin \& Sohirin M. Solihin. 2012. Al-manhaj al-haraki fi Tafsir al-Quran bayna alasalah wa al-tajdid. Jurnal al-Bayan 10(2).

al-Husayn, Musa Qasim. 2010. Dr Sayid Nuh Rahimahu Allah: qissah da`iyah. Kuwait: Kementerian Wakaf Kuwait.

al-Khalidi, Salah. 2000. Al-manhaj al-haraki fi zilal al-Quran. cet ke-2. Amman: Dar Ammar.

al-Khalidi, Salah. 2010. Ta'rif al-darisin bi manahij al-mufassirin. Cet. Ke-4. Damascus: Dar alQalam.

al-Khalidi, Salah. 2012. Interview. June, 20.

Makki, Hasan. 1995. Mafahim fi Fiqh al-Harakah. t.tp.: al-Harakah al-Islamiyyah al-Tullabiyyah.

Nabil bin Muhammad bin Ibrahim al-Jauhari. 2013. Interview. May, 15. 
Qutb, Sayyid. 1979. Ma`alim fi al-tariq. Cet. Ke-6. Beirut: Dar al-Syuruq.

Said, Hammam. 2012. Muraqib `Am Ikhwan Muslimin Jordan. Interview. June, 21.

Sawrah, Muhammad b. Isa. 2002. Sunan al-Tirmidhi. Beirut: Dar al-Ma'rifah.

Sayyid Nuh .1994. Min akhlaq al-nasr fi jiyl al-Sahabah. Beirut: Dar Ibn Hazm.

Sayyid Nuh. 1991. Manhaj Ahl al-Sunnah wa al-Jamaah fi qadiyyah al-taghyir bi janibayh altarbawi wa al-da 'awi. Cet. ke-2. Mansoura: Dar al-Wafa.

Sayyid Nuh. 2004. Pesan-pesan Nabi (s.a.w.): Syarah Hadits dalam perspektif dakwah\& tarbiyah. Transl. Jakarta: Fadhli Bahri al-Nadwah.

Sayyid Muhammad Nuh. 2013. www.alsayednooh.com. [7 Okt 2013].

Ubadah Syed Nuh. 2012. Interview. Jun, 4.

Wasfy Asyur Abu Zaid. 2012. Interview. Jun, 4.

Yahya Ismail. 2012. Interview. Jun, 8.

Yakan, Fathi. 1988. Musykilat al-da wah wa al-da `iyah. Beirut: Muassasah al-Risalah. 